\title{
KUIDAS ARENEB EESTI ÕPPIJAKEEL JA MIKS JUST NII - KAS ÕPPIJAKEELEKORPUS ANNAB NEILE KÜSIMUSTELE VASTUSED?
}

\author{
MARE KITSNIK
}

$\mathrm{E}$ esti keele kui teise keele õppe- ja hindamissüsteem põhineb Euroopa keeleõppe raamdokumendil (EKR 2007) nagu kogu Euroopa teiste keelte õppe- ja hindamissüsteem. Raamdokumendis on toodud kõigi keelte kohta kehtivad kommunikatiivse keelepädevuse kirjeldused kuue keeleoskustaseme kaupa: A1 ja A2 ehk algaja keeleomandaja, B1 ja B2 ehk iseseisev keelekasutaja, C1 ja C2 ehk keelevaldaja. Kommunikatiivse keelepädevuse arengut nähakse nii horisontaalselt (inimene tuleb toime järjest rohkemate suhtlusülesannetega) kui ka vertikaalselt (täidetavad ülesanded muutuvad üha keerukamaks ning neid täidetakse järjest paremini) (EKR 2007: 31-33).

Kommunikatiivse keelepädevuse areng käib käsikäes leksikaalgrammatilise arenguga. Suurema arvu keerukamate suhtlusülesannete parem täitmine nõuab ka suurema arvu keerukamate keelekonstruktsioonide kasutamist. Leksikaalgrammatilise pädevuse kohta on raamdokumendis infot väga napilt, sest vaatamata teatud üldistele seaduspärasustele on selles palju keelespetsiifilist. Samas vajavad keeleõppijad, -õpetajad, -hindajad jt täpsemat infot, milline sõnavara ja grammatilised struktuurid ning millised kõrvalekalded standardist on igale keeleoskustasemele iseloomulikud. Leksikaalgrammatilisi kirjeldusi ei saa luua kõigi keelte kohta ühiselt, vaid need peavad looma iga keele eksperdid ise. Mitmete Euroopa keelte kohta on sellised kirjeldused juba loodud või loomisel (vt Language Policy Portal), neist kõige tuntum English Profile. Selleks on palju kasutatud ka viimastel aastakümnetel hoogustunud korpusuuringuid, mis võimaldavad uurida suuremahulist autentset õppijakeelt ning leida sellele iseloomulikke jooni keeleoskustasemete kaupa (vt LCA).

Eesti keele kui teise keele kohta on olemas raamdokumendil põhinevad käsiraamatud (Hausenberg jt 2008; Kerge 2008; Ilves 2008, 2010), milles täpsustatakse kommunikatiivseid kirjeldusi eesti keele kohase leksikaalgrammatilise infoga. Olles ise autorite rühma koostöös esimesena ilmunud B1- ja B2-taseme käsiraamatu leksikaalgrammatiliste kirjelduste põhiautor, tean, et need kirjeldused põhinevad peamiselt autorite kogemusel ja intuitsioonil ning ainult mõnel üksikul teaduslikul uurimusel. Seega on suur vajadus keeleoskustasemete leksikaalgrammatilise sisu teaduspõhise uurimise järele. Selleks on nüüd võimalik kasutada ka õppijakeelekorpusi, mida Eestis on praegu kaks. Tallinna Ülikoolis on loodud eesti vahekeele korpus (EVKK), mis sisaldab eesti keele kui teise keele õppijate tekste ning millel on mitmeid erilaadseid korpusuurimusi võimaldavaid vahendeid (vt lähemalt Eslon 2014a). Tartu Ülikoolis on õppijakeelekorpus (ÕKK), mis sisaldab samuti eesti keele 
kui teise keele õppijate tekste, ning selle juurde kuuluv paralleelkorpus, milles asuvad B1- ja B2-keeleoskustasemega õppijate kirjalike tööde keelevigadega laused. Korpuste põhjal on õppijakeelt uurinud Pille Eslon (2011, 2012, 2014b, 2014c, 2017), Kais Allkivi (2016) ja Diana Maisla (2014). Nendes uurimustes on käsitletud õppijakeelt tervikuna, tasemeid eristamata, või vaadeldud vaid kõige kõrgema tasemega eesti keele õppijate keelt. Seega on õppijakeele olulisimat omadust, selle arengut, siiani õigustamatult vähe uuritud.

Käesolev artikkel käsitleb õppijakeele leksikaalgrammatilist arengut tasemetel B1 ja B2. Osades 1-3 kirjeldan, millised muutused on B2-tasemel toimunud võrreldes B1-tasemega. Teen seda nende tasemete vahel märgatavalt arenenud tingiva kõneviisi ja modaalverbi võima konstruktsioonide näitel. Neljandas osas põhjendan, miks konstruktsioonid B1- ja B2-taseme vahel just sel viisil arenevad. Kasutatud andmed on osaliselt ilmunud varasemates publikatsioonides (Kitsnik 2014, 2015, 2017), siinses artiklis on need esitatud edasiarendatult ja uutes seostes.

\section{Kuidas muutub kommunikatiivse keeleoskustaseme tõustes õppijakeele leksikaalgrammatiline pädevus?}

Õppijakeele leksikaalgrammatilist arengut kirjeldan kahe B1- ja B2-taset eristava verbikonstruktsiooni kaudu. B-tase on kommunikatiivse keelepädevuse arengus keskne: alates sellest tasemest suudab inimene hakkama saada iseseisva suhtlemisega õpitavas keeles. Vaatamata sarnasele tähistusele on B1- ja B2-tase siiski üsna erinevad. B1-tasemel tullakse toime igapäevase olmesuhtlusega, B2-tasemel lisandub ühiskondlik mõõde, saadakse aru meediast ning suudetakse suhelda nõudlikumates tööalastes situatsioonides (vt lähemalt nt EKR 2007: 49-51). B1-tasemelt B2-tasemele jõudmine on seega keeleomandaja jaoks märkimisväärne kvantitatiivne ja kvalitatiivne hüpe. Täiskasvanute riiklike eesti keele kui teise keele B2-taseme eksami suhteliselt madal sooritusprotsent (30-40\%, vt Innove tasemeeksamite statistika) näitab selle hüppe sooritamise raskust paljude inimeste jaoks. Seega on nii õppijail kui ka õpetajail oluline mõista, kuidas arenevad B1- ja B2-taseme vahel keelekonstruktsioonid, mis võimaldavad kommunikatiivsete ülesannetega toime tulla.

Artikli aluseks olevate uurimuste materjaliks on olnud täiskasvanute B1- ja B2-taseme riiklike eksamite kirjutamisülesannete sooritused, mis asuvad eesti vahekeele korpuses. Sealsete tekstide põhjal olen koostanud kaks töökorpust: B1-taseme korpus (24 624 sõnet) ja B2-taseme korpus (21 783 sõnet). Töökorpustesse olen võtnud eksamisooritused, mida riiklikud hindajad on hinnanud vastava taseme kohaseks (vt täpsemalt Kitsnik 2014: 14). Uurimismeetodina olen kasutanud korpusest tulenevat (ingl corpus-driven) lähenemist: see tähendab, et olen valinud uurimiseks need konstruktsioonid, mis korpusest esinemissageduse põhjal esile kerkisid. Konstruktsioone olen uurinud nii kvantitatiivselt kui ka kvalitatiivselt, kasutades seejuures Jyväskylä uurijate välja töötatud mudelit DEMfad (Franceschina jt 2006; Martin jt 2010; vt lähemalt Kitsnik 2014: 15-18). Kvantitatiivselt olen vaadelnud konstruktsioonide morfoloogiliste, süntaktiliste, leksikaalsete ja funktsionaalsete 
tüüpide sagedusi tuhande sõne kohta ja osakaale kõigist konstruktsioonidest ning täpsete ja ebatäpsete konstruktsioonide vahekorda. Erinevused B1- ja B2-taseme vahel on määratud tõenäosuspõhiselt (v.a tingiva kõneviisi üldise esinemissageduse korral, millel on määratud ka statistiline olulisus). Sel viisil saab uurida üldisi suundumusi, mida töö järgmistes etappides võiks testida suuremamahulise materjali peal. Kvalitatiivselt olen analüüsinud konstruktsioonide tähendusi ja suhtlusfunktsioone ning sisulist täpsust konteksti põhjal.

Uurimistulemuste kirjeldamisel olen kasutanud maailmas teise keele uurimisel levinud CAF-triaadi kaht dimensiooni: $\mathrm{C}=$ complexity (ee keerukus), ja $\mathrm{A}=$ accuracy (ee täpsus) (Housen jt 2012: 2-10). Keerukus on leksikaalgrammatiliste vormide ja nendega edastatavate tähenduste ning suhtlusfunktsioonide kombineerumisvõimaluste hulk. Keerukuse uurimisel olen arvestanud konstruktsiooni eri tüüpide arvu ja osakaalu kõigist konstruktsioonidest. Täpsus on keelekasutuse vastavus normile, kusjuures normiks peetakse üldiselt emakeelse kogukonna tavapärast keelekasutust, mitte akadeemilisi keelereegleid. Täpseks olen määranud konstruktsioonid, mis ei mõju ei vormilises ega sisulises mõttes mulle kui eesti keelt esimese keelena kõnelejale häirivalt. Olen vaadelnud nii täpsete ja ebatäpsete konstruktsioonide absoluutarvu kui ka nende osakaalu kõigist konstruktsioonidest. Kolmandat dimensiooni $\mathrm{F}$ = fluency (ee sujuvus) on tavaks mõõta suulises kõnes ja seda ma oma uurimustes pole kasutanud. CAF-triaadi põhised uurimused on näidanud, et keeleoskuse arenedes muutub õppijakeel keerukamaks, täpsemaks ja sujuvamaks, see ei toimu aga ühtlaselt tõusvas joones. Eri dimensioonide areng kulgeb eri kujul ja eri kiirusega ning ajutiselt esineb ka tagasiminekut.

Olen välja selgitanud kaks konstruktsiooni, mis on B2-tasemel võrreldes B1-tasemega märgatavalt arenenud: tingiva kõneviisi ja modaalverbi võima konstruktsioonid (vt joonist 1). Järgnevalt kirjeldan nende konstruktsioonide esinemissageduse, morfoloogilise, süntaktilise, leksikaalse ja funktsionaalse keerukuse ning täpsuse arengut. Teises osas käsitlen tingiva kõneviisi ja kolmandas osas modaalverbi võima konstruktsioone.

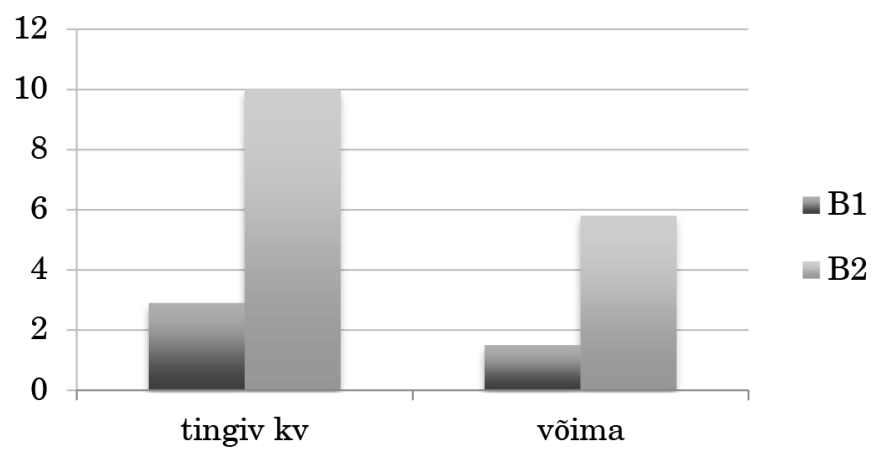

Jo o n is 1. Tingiva kõneviisi ja modaalverbi võima konstruktsioonide esinemissagedus B1- ja B2-tasemel (kordades tuhande sõne kohta). 


\section{Tingiva kõneviisi konstruktsioonide areng}

Esimesena kerkis töökorpustest esile tingiv kõneviis, mille esinemissageduse erinevus B1- ja B2-taseme vahel on märgatav ja ka statistiliselt oluline (vt Kitsnik 2014: 20). Kui B1-tasemel on tingiva kõneviisi sagedus 2,9 esinemisjuhtu tuhande sõne kohta, siis B2-tasemel on sagedus tõusnud 3,4 korda ja jõudnud 10 esinemiseni tuhande sõne kohta. See erinevus tekitas huvi uurida konstruktsiooni arengut lähemalt ja järgnevalt kirjeldangi tingiva kõneviisi morfoloogilise, süntaktilise, leksikaalse ja funktsionaalse keerukuse ning täpsuse arengut B1- ja B2-taseme vahel.

\subsection{Tingiva kõneviisi konstruktsioonide morfoloogilise keerukuse areng}

Morfoloogiline keerukus on üks keerukuse alaosa, mida eesti keele morfoloogilise rikkuse tõttu tasub kindlasti eraldi vaadelda. Järgnevalt kirjeldan, millistes morfoloogilistes vormides kaldub tingiv kõneviis B1- ja B2-tasemel esinema, ning võrdlen, mis tasemeid eristab.

Nii B1- kui ka B2-tasemel esinevad kõik seitse tingiva kõneviisi isikulise tegumoe olevikuvormi (kuus isikut ja eitav vorm). Isikulise tegumoe minevikuvorme ega umbisikulise tegumoe vorme ei esine tingivas kõneviisis kummalgi tasemel. Muutused on aga toimunud tingiva kõneviisi pöördevormide sageduses ja osakaalus (vt joonist 2).

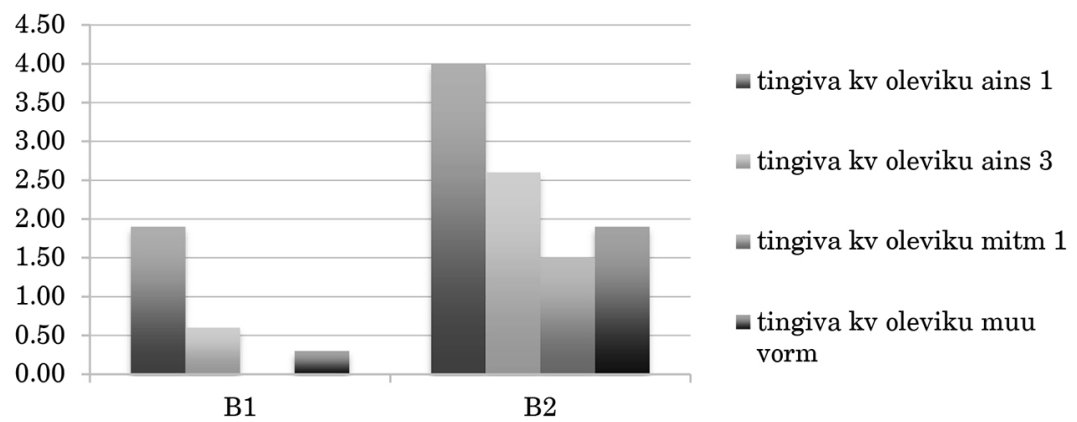

Joonis 2. Tingiva kõneviisi konstruktsioonide morfoloogiline keerukus B1- ja B2-tasemel. Vertikaaltelg näitab esinemissagedust tuhande sõne kohta.

Et B2-tasemel on tingiva kõneviisi üldine sagedus tõusnud üle kolme korra, peavad arusaadavalt tõusma ka eri pöördevormide absoluutsed sagedused. Huvitav on aga vaadelda, millised muutused on toimunud eri pöördevormide osakaalus. Nagu jooniselt 2 näha, on kummalgi tasemel esikohal oleviku ainsuse esimese pöörde vormid, kuid nende osakaal on B2-tasemel vähenenud: B1 sagedus 1,9 esinemist tuhande sõne kohta, osakaal kõigist vormidest $66 \%$ (näide 1); B2 sagedus 4 esinemist tuhande sõne kohta, osakaal 40\% (näide 2). 
(1) Tahaksin teada veel maailmast. (B1)

(2) Ma sooviksin saada teie firma täpsemat info. (B2)

Teisel kohal on kummalgi tasemel sarnaselt ainsuse kolmanda pöörde vormid: B1 sagedus 0,6 esinemist, osakaal $21 \%$ (näide 3 ); B2 sagedus 2,6 esinemist, osakaal $26 \%$ (näide 4).

(3) See oleks huvitav tulevikus marimaale reisida. (B1)

(4) Selleks, et kõik edukas oleks, on vaja raha [---] (B2)

B2-tasemel on ilmunud mitmuse esimese pöörde vormid: 1,5 esinemist tuhande sõne kohta, osakaal 15\% (näide 5). Veel on B2-tasemel tõusnud tingiva kõneviisi muude vormide sagedus ja osakaal: B1 sagedus 0,3 esinemist tuhande sõne kohta, osakaal 10\%; B2-tasemel sagedus 1,9 esinemist ja osakaal $19 \%$.

(5) Peale selle me tahaksime tellida tee ja kohv, sest meie kollektiiv ei tarvitata alkohoolijoogid. (B2)

Kokkuvõttes on näha tingiva kõneviisi morfoloogilist arengut B2-tasemel võrreldes B1-tasemega: vähenenud on esikohal oleva konstruktsiooni osakaal ning tõusnud teiste konstruktsioonide osakaalud.

\subsection{Tingiva kõneviisi konstruktsioonide süntaktilise keerukuse areng}

Tingiva kõneviisi süntaktilist keerukust olen vaadelnud konstruktsiooni peasõna ja selle juurde kuuluva ühe sõna/sõnaühendi ulatuses, nt tahaksin kindlustada. Süntaktiliste tüüpide esinemissagedused on kujutatud joonisel 3.

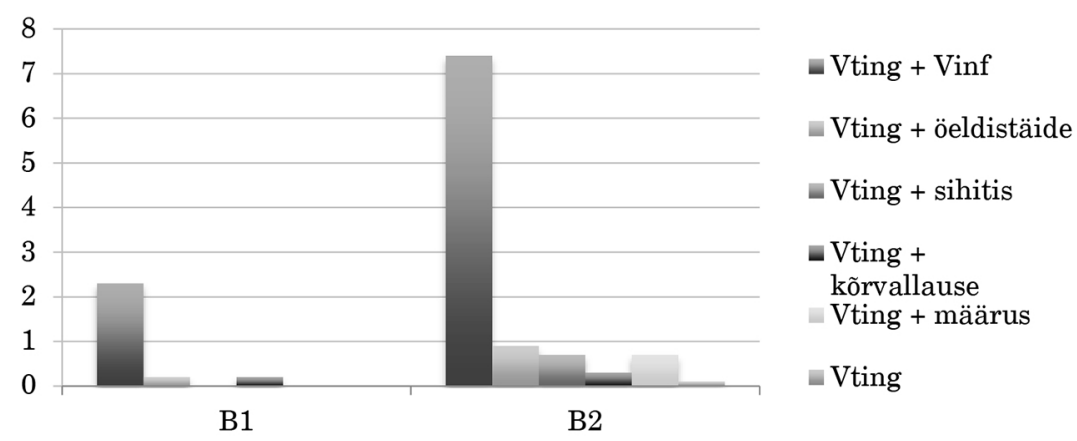

Joonis 3. Tingiva kõneviisi konstruktsioonide süntaktiline keerukus B1- ja B2-tasemel. Vertikaaltelg näitab esinemissagedust tuhande sõne kohta.

Niimoodi vaadeldes domineerib nii B1- kui ka B2-tasemel suure ülekaaluga tüüp verb tingivas kõneviisis + verbi infinitiivivorm (B1-tasemel 2,3 esinemist 
ja B2-tasemel 7,4 esinemist tuhande sõne kohta, näited 6 ja 7). Seejuures on selle tüübi osakaal B2-tasemel kahanenud 74\%-ni võrrelduna B1-taseme $79 \%$-ga.

(6) Kas sa ühislikult ei saaks koos minuga minna kontserdile? (B1)

(7) Kõigepealt ma sooviksin kindlustada minu korter. (B2)

Kõiki teisi süntaktilisi tüüpe esineb kummalgi tasemel vähe. Ometi on näha, et kui B1-tasemel esinevad lisaks infinitiivitüübile veel vaid öeldistäite ja kõrvallausega tüübid, siis B2-tasemel on ilmunud ka sihitise, määruse ja laienditeta tüübid. Seega võib tingiva kõneviisi juures märgata ka väikest süntaktilise keerukuse arengut: domineeriva konstruktsiooni osakaal on B2-tasemel veidi vähenenud ning eri süntaktiliste tüüpide arv kasvanud. Süntaktilist keerukust tasuks kindlasti edasi uurida konstruktsiooni peasõna juurde kuuluva mitme sõna/sõnaühendi ulatuses.

\subsection{Tingiva kõneviisi konstruktsioonide leksikaalse keerukuse areng}

Tingiva kõneviisi leksikaalse jaotuvuse uurimisel olen vaadelnud, milliste verbidega tingivat kõneviisi kummalgi tasemel kasutatakse. Tulemused näitavad, et B1-tasemel esineb tingivas kõneviisis kaheksa eri verbi, millest seitse (olema, saama, tulema, pidama, võima, tahtma, kirjutama) on eesti keeles kõrge esinemissagedusega ja üks verb (soovima) veidi madalama sagedusega. ${ }^{1}$ Seejuures esineb tingiv kõneviis valdavalt kahe verbiga: tahtma ja saama.

B2-tasemel on tingivas kõneviisis olevate verbide arv kasvanud 23-ni. Nende hulgas on kümme eesti keeles kõrge esinemissagedusega verbi (olema, saama, pidama, tegema, minema, võima, võtma, tahtma, küsima ja vastama) ning kolmteist madalama sagedusega tegusõna (mängima, aitama, toimuma, soovima, sõlmima, sobima, soovitama, tellima, põhjendama, asendama, laiendama, abistama, nõus olema). Peamiselt kasutatakse tingivat kõneviisi kuue verbiga: tahtma, olema, võima, pidama, soovima, soovitama.

Seega on tingiva kõneviisi leksikaalne keerukus B2-tasemel võrreldes B1-tasemega märgatavalt kasvanud nii tingivas kõneviisis esinevate eri verbide arvu kolmekordse tõusu kui ka eesti keeles madalama esinemissagedusega verbide kasutama hakkamise tõttu.

\subsection{Tingiva kõneviisi konstruktsioonide funktsionaalse keerukuse areng}

Et lisaks vormile on väga oluline konstruktsioonidega väljendatav tähendus ja samuti nende suhtlusfunktsioon, olen järgmisena vaadelnud, milliseid üldiseid suhtlusfunktsioone tingiva kõneviisiga väljendatakse. Et mõnikord võib

${ }^{1}$ Kõrge sagedusega verbideks olen määratlenud üle 500 esinemiskorra ja madala sagedusega alla 500 esinemiskorraga verbid eesti kirjakeele sagedussõnastikus (Kaalep, Muischnek 2002). 
sama konstruktsioon väljendada korraga mitut suhtlusfunktsiooni, ei ole ma siinkohal teinud kvantitatiivseid kokkuvõtteid.

Uurimusest on ilmnenud, et tingiva kõneviisi konstruktsioone kasutatakse nii B1- kui ka B2-tasemel samades üldistes suhtlusfunktsioonides. Kõigepealt väljendatakse tingiva kõneviisiga üldiseid soove (näide 8).

(8) Kuulsin, et järgmisel aastal toimub samasugune kursus jälle, tahaksin sinna veel kord minna. (B1)

Teiseks kirjeldatakse tingiva kõneviisiga teatud tingimustel toimuda võivat tegevust (näide 9).

(9) Ma soovin kindlustada minu korterit ühele aastale ja kui mulle meeldis teie firma tingimused, siis võib olla ma sõlmiksin leping veel ühte aastaks. (B2)

Kolmandaks kasutatakse tingivat kõneviisi viisakuse väljendamiseks: edastatava info või küsimuse sujuvamaks sissejuhatuseks (näide 10) ja jutustava teksti lugeja poole pöördumiseks (näide 11).

(10) Kas te võiksite oma vastusega saata ka teie menüü, et me tutvusime sellega. (B2)

(11) See oli nii huvitav ja ma tahaksin sellest kirjutada. (B1)

Seega ei ole tingiva kõneviisi funktsionaalne keerukus B2-tasemel üldiste suhtlusfunktsioonide osas kasvanud. Funktsionaalse keerukuse uurimist tasuks edaspidi jätkata, näiteks võiks uurida tingiva kõneviisi kasutust tekstitüüpide kaupa.

\subsection{Tingiva kõneviisi konstruktsioonide täpsuse areng}

Viimasena olen jälginud konstruktsioonide täpsust. Konstruktsiooni olen hinnanud täpseks, kui see ei mõju mulle kui eesti keelt esimese keelena kõnelejale ei vormiliselt ega sisuliselt häirivalt. Täpsuse vormilist külge olen hinnanud konstruktsiooni peasõna ja tema juurde kuuluva ühe sõna/sõnaühendi ulatuses. Sisulist täpsust hinnates olen arvestanud ka konstruktsiooni laiemat konteksti. Joonisel 4 on kujutatud tingiva kõneviisi konstruktsioonide täpsete ja ebatäpsete esinemisjuhtude sagedused.

B1-tasemel esineb tingiva kõneviisi täpseid konstruktsioone 2 korda ja ebatäpseid 0,9 korda tuhande sõne kohta. B2-tasemel on sagedused tõusnud nii täpsete (8,4 esinemist tuhande sõne kohta) kui ka ebatäpsete konstruktsioonide (1,6 esinemist tuhande sõne kohta) osas. Kui võrrelda aga täpsete konstruktsioonide osakaalu kõigist tingiva kõneviisi konstruktsioonidest, siis B1-tasemel on täpseid konstruktsioone $69 \%$ ja B2-tasemel $84 \%$ kõigist esinemisjuhtudest - nii võib öelda, et tingiva kõneviisi konstruktsioonide üldine täpsus B2-tasemel tõuseb. 


\section{10
8
6
4
2
0}

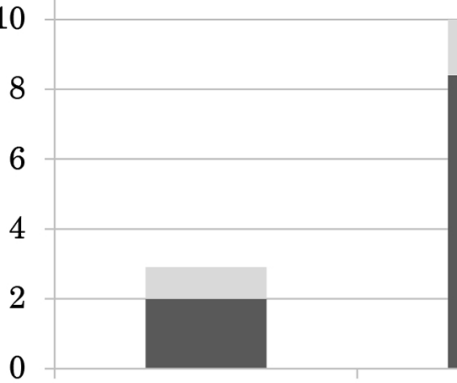

B1

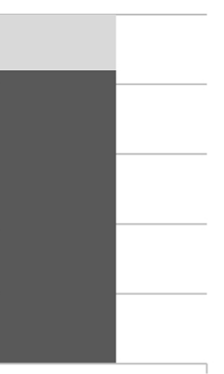

B2 ebatäpsed tingiva kv konstruktsioonid

- täpsed tingiva $\mathrm{kv}$ konstruktsioonid

Jo on is 4. Tingiva kõneviisi täpsete ja ebatäpsete konstruktsioonide esinemissagedus B1- ja B2-tasemel. Vertikaaltelg näitab esinemissagedust tuhande sõne kohta.

Kokkuvõttes näitavad uurimistulemused, et tingiva kõneviisi konstruktsioonid on B2-tasemel võrreldes B1-tasemega arenenud nii morfoloogiliselt kui ka süntaktiliselt ja eriti märgatavalt leksikaalselt. Samuti on B2-tasemel tõusnud tingiva kõneviisi konstruktsioonide üldine täpsus, samas on veidi tõusnud ka ebatäpsete konstruktsioonide absoluutarv.

\section{Modaalverbi võima konstruktsioonide areng}

Teise olulise B1- ja B2-taseme eristajana on minu uurimustes esile tõusnud modaalverbi võima konstruktsioonid. Nagu jooniselt 1 näha, tõuseb ka võimakonstruktsioonide esinemissagedus kahe uuritava taseme vahel märgatavalt: 3,9 korda ehk B1-taseme 1,5 esinemisjuhult B2-taseme 5,8 esinemisjuhuni tuhande sõne kohta. Seetõttu olen uurinud üksikasjalikumalt ka nende konstruktsioonide arengut. Järgnevalt kirjeldan võima-konstruktsioonide morfoloogilist, süntaktilist, leksikaalset ja funktsionaalset keerukust ning täpsust.

\section{1. võima-konstruktsioonide morfoloogilise keerukuse areng}

Modaalverbi võima konstruktsioonid esinevad nii B1- kui ka B2-tasemel peamiselt isikulise tegumoe kindla ja tingiva kõneviisi olevikuvormides. B2-tasemel esineb ka paar kindla kõneviisi lihtminevikuvormi. Umbisikulise tegumoe ja isikulise tegumoe täis- ega ennemineviku vorme võima-konstruktsioonides ei kasutata. Muutused võima-konstruktsiooni eri morfoloogiliste vormide sagedustes B1- ja B2-tasemel on kujutatud joonisel 5. 


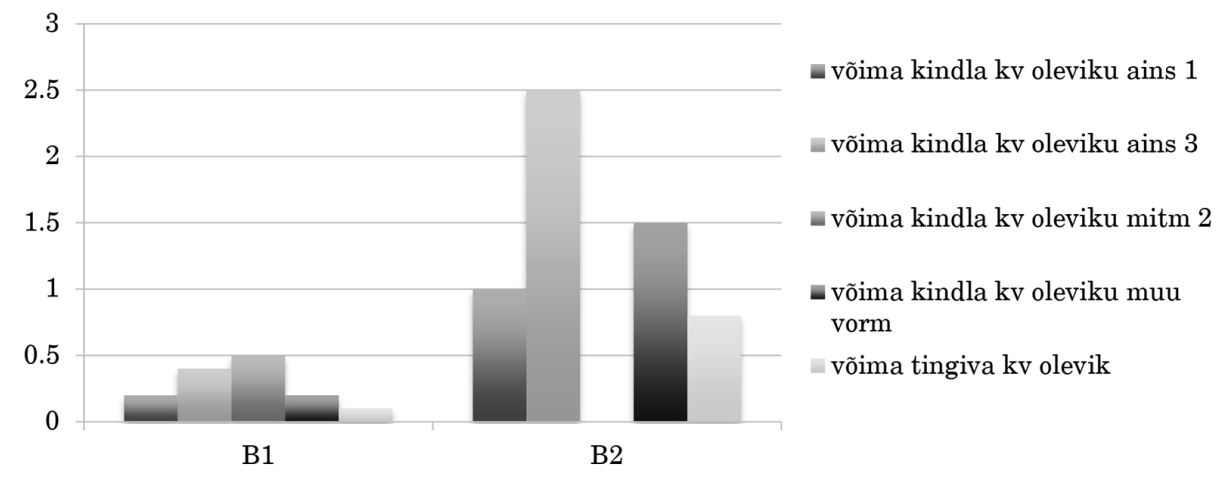

J o on is 5. Modaalverbi võima morfoloogiline keerukus B1- ja B2-tasemel. Vertikaaltelg näitab esinemissagedust tuhande sõne kohta.

B1-tasemel esineb võima-konstruktsioone vähe ning ükski morfoloogiline vorm ei domineeri. Kõige sagedasemad on kindla kõneviisi oleviku mitmuse teise pöörde vormid: sagedus 0,5 esinemist tuhande sõne kohta, osakaal $33 \%$ kõigist tingiva kõneviisi konstruktsioonidest (näide 12).

(12) Edaspidi võite kontaktida mind telefoni teel, minu number on [---]. (B1)

B2-tasemel on võrreldes B1-tasemega kasvanud kõigi morfoloogiliste vormide sagedused, välja arvatud kindla kõneviisi mitmuse teine pööre. Kõige rohkem on kasvanud esimesele kohale tõusnud kindla kõneviisi oleviku ainsuse kolmanda pöörde vormide esinemissagedus ja osakaal: B1 sagedus 0,4 esinemist tuhande sõne kohta, osakaal 27\% kõigist konstruktsioonidest (näide 13); B2 sagedus 2,5 esinemist, osakaal $43 \%$ (näide 14).

(13) Kui teil on veel küsimused, võib alati helistada mulle. (B1)

(14) Autoga tööle käimist võib asendada ka jalutuskäiguga, see on meie tervisele ja loodusele kasulikum. (B2)

Teisel kohal on B2-tasemel muude kindla kõneviisi olevikuvormide sagedus ja osakaal, mis on samuti võrreldes B1-tasemega tõusnud (B1 sagedus 0,2 esinemist tuhande sõne kohta, osakaal 13\%; B2-sagedus 1,5 esinemist, osakaal 26\%). Tõusnud on ka kindla kõneviisi ainsuse esimese pöörde sagedus ja veidi ka osakaal (B1 sagedus 0,2 esinemist, osakaal 13\%; B2 sagedus 1 esinemine tuhande sõne kohta, osakaal 17\%). Lisaks on B2-tasemel tõusnud tingiva kõneviisi olevikuvormide sagedus ja osakaal (B1 sagedus 0,1 esinemist, osakaal 7\%, näide 15; B2 sagedus 0,8 esinemist, osakaal 14\%, näide 16).

(15) Kus me võiks kohtuda jargmisel ajal. (B1)

(16) Aga praegu saad küsida teistelt kolleegidelt, kas võiksid sind asendada. (B2) 
Seega arenevad võima-konstruktsioonid B2-tasemele jõudes morfoloogiliselt võrreldes B1-tasemega eelkõige kognitiivselt keerukamate kindla kõneviisi ainsuse kolmanda pöörde ja tingiva kõneviisi vormide sageduse ja osakaalu tõusu tõttu, aga ka peaaegu kõigi teiste vormide sageduse tõusu tõttu.

\section{2. võima-konstruktsioonide süntaktilise keerukuse areng}

Süntaktilist keerukust olen vaadelnud võima-konstruktsiooni peasõna ja selle juurde kuuluva kahe sõna/sõnaühendi ulatuses, nt ennast võib rõommustada. Konstruktsioonide süntaktiliste tüüpide sagedused on kujutatud joonisel 6.

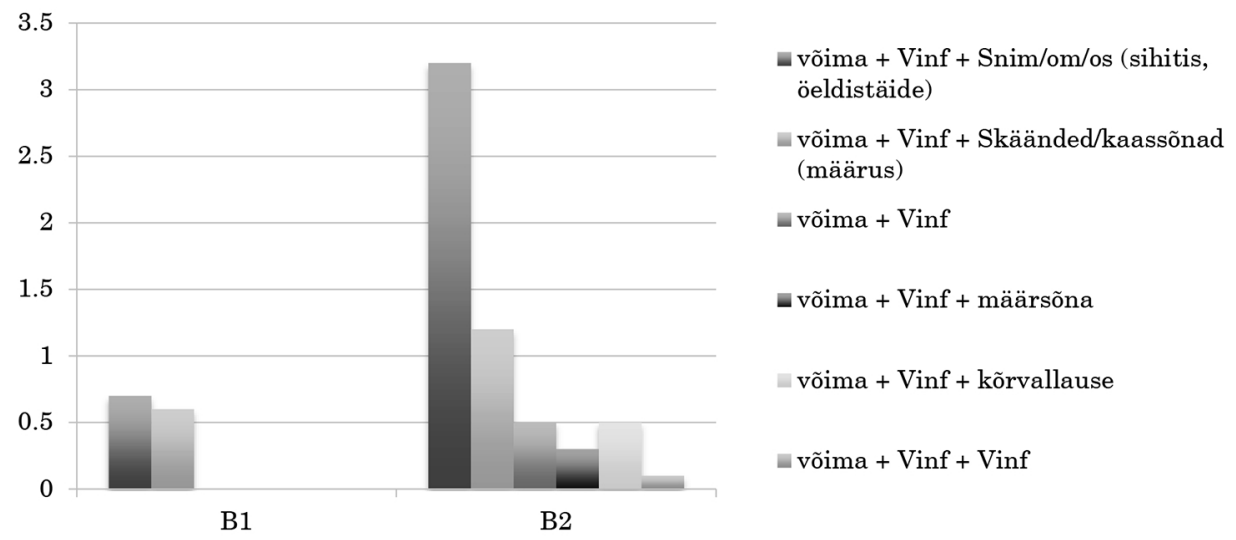

Joonis 6. Modaalverbi võima konstruktsioonide süntaktilised tüübid B1- ja B2-tasemel. Vertikaaltelg näitab esinemissagedust tuhande sõne kohta.

B1-tasemel esinevad võima-konstruktsioonid peamiselt kahes süntaktilises tüübis: võima pöördeline vorm koos verbi infinitiivivormiga ja sihitise (või väga harva öeldistäite) rollis käändsõna(ühendi)ga (sagedus 0,7 esinemist tuhande sõne kohta, osakaal $47 \%$ kõigist võima-konstruktsioonidest, näide 17) ning võima pöördeline vorm koos verbi infinitiivivormiga ja määruse rollis käändsõna(ühendi)ga (sagedus 0,6 esinemist tuhande sõne kohta, osakaal $40 \%$, näide 18). Esineb veel kaks tüüpi, kuid neid on nii vähe, et sageduseks kujuneb null esinemist tuhande sõne kohta.

(17) Te võite selga panna ainult mugav riietus. (B1)

(18) Kui soovite osaleda siis võib registrerida säkritari juures või e-maili teel. (B1)

B2-tasemel on võima-konstruktsioonide süntaktiliste tüüpide arv kasvanud seitsmeni, millest ühe esinemisjuhtude arv on nii väike, et sageduseks kujuneb null tuhande sõne kohta. Sageduse ja osakaalu poolest on B2-tasemel võrreldes B1-tasemega kõige rohkem kasvanud verbi infinitiivivormi ja 
sihitise rollis käändsõna(ühendi)ga tüübi esinemine (B2 sagedus 3,2 esinemist tuhande sõne kohta, osakaal 55\%, näide 19 ).

(19) Mina ostsin korteri väga vanas majas ja seepärast mul on hirmus, et seal võib midagi juhtuda, näiteks elektrivõrkuga. (B2)

Ka verbi infinitiivivormi ja määruse rollis käändsõna(ühendi)ga tüübi sagedus on kasvanud (B2 sagedus 1,2 esinemist tuhande sõne kohta), kuid osakaal võrreldes B1-tasemega selgelt kahanenud (B2 osakaal 21\%, näide 20).

(20) Aga kui ei saa hakama stressiga võib pöörduda arsti poole. (B2)

B2-tasemel esineb veidi ka ilma laiendita infinitiivivorme (näide 21) ja infinitiivivorme koos kõrvallausega (näide 22), kumbagi 0,5 esinemiskorda tuhande sõne kohta.

(21) Hästi, et mõnikord nad võivad sõidata ära ning töötada. (B2)

(22) Kokkuvõtteks on võib öelda, et tingimata eluraskused teevad inimese tugevaks, kõige olulisem on vaja olla sihikindel inimese. (B2)

Ülejäänud B2-taseme süntaktiliste tüüpide sagedus ja osakaal on väiksem. Kokkuvõttes võib öelda, et võima-konstruktsioonid on B2-tasemel võrreldes B1-tasemega süntaktiliselt arenenud: eri süntaktiliste tüüpide arv on kasvanud ning tõusnud on infinitiivivormi ja sihitise rollis käändsõna(ühendi)ga kui kognitiivselt keerukama tüübi sagedus ning osakaal.

\section{3. võima-konstruktsioonide leksikaalse keerukuse areng}

võima-konstruktsioonide leksikaalse keerukuse arengut olen vaadelnud ühe sõna/sõnaühendi ulatuses, nt võib rõõmustada. Sel viisil olen leidnud, kui palju eri sõnu/sõnaühendeid konstruktsiooni peasõna juurde kuulub. Tulemused näitavad, et B1-tasemel esineb koos modaalverbiga võima 31 eri verbi/ verbiühendit ning B2-tasemel on see arv kasvanud 63-ni ehk kaks korda. Seega on võima-konstruktsioonid B2-tasemel ka leksikaalselt arenenud ning õppijakeele keerukus selles osas tõusnud.

\section{4. võima-konstruktsioonide funktsionaalse keerukuse areng}

võima-konstruktsioonide funktsionaalset keerukust olen määranud nendega väljendatavate modaalsuse tüüpide järgi. võima funktsioonide eristamisel olen aluseks võtnud „Eesti keele seletava sõnaraamatu” (EKSS) jaotuse, mida olen interpreteerinud lähtuvalt Mati Erelti modaalsuse liigitusest (Erelt 2013). Sel viisil olen jaganud võima-konstruktsioonid kuude modaalsuse tüüpi, mis väljendavad: 1) võimalikkust (osalejavälist mittedeontilist modaalsust 'kellelgi on võimalus midagi teha', nt ringkonnakohtu otsuse võib edasi kaevata); 2) lubatust (osalejavälist deontilist modaalsust 'kellelgi on õigus midagi teha', nt kas 
siin võib suitsetada?); 3) võimet (osalejasisest dünaamilist modaalsust 'miski on võimalik tegija võimete, suutlikkuse tõttu', nt ta oli nii jutukas, et võis kõik tummaks rääkida); 4) tõenäolisust (episteemilist modaalsust 'sündmus või olukord on võimalik, mõeldav või tõenäoline kõnelejast sõltumatute asjaolude tõttu', nt kolme aastaga võis kutsekoolis omandada korraliku elukutse); 5) põhjendatust (osalejavälist mittedeontilist modaalsust 'olukorrast tingitud põhjendatus', nt sellist nähtust võib pidada väga haruldaseks); 6) soovitatavust, mõistlikkust kõneleja arvates (osalejavälist mittedeontilist modaalsust, kus verb on harilikult tingivas kõneviisis, nt külalised võiksid juba tulla). võima-konstruktsioonide funktsionaalsete tüüpide sagedused on kujutatud joonisel 7.

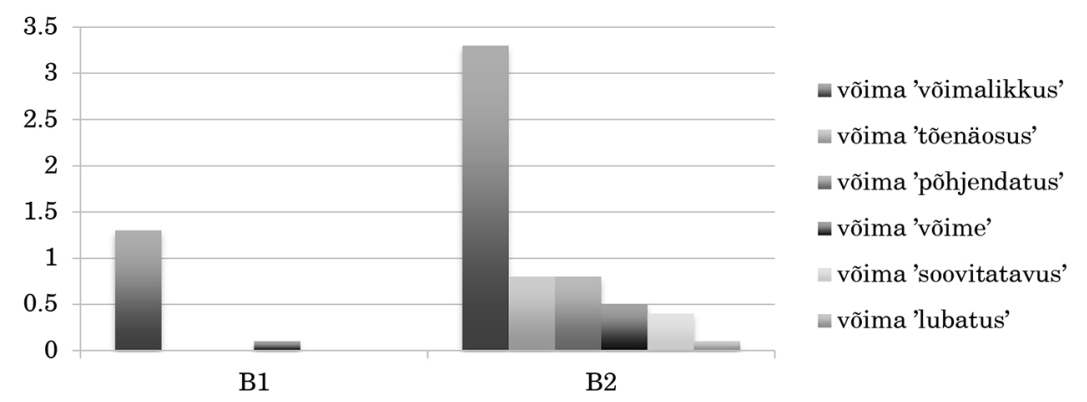

Joonis 7. Modaalverbi võima konstruktsioonide funktsionaalsed tüübid. Vertikaaltelg näitab esinemissagedust tuhande sõne kohta.

Nagu jooniselt 7 näha, domineerib kummalgi keeleoskustasemel võimalikkuse (osalejavälise mittedeontilise modaalsuse) väljendamine. B1-tasemel on selle tüübi sagedus 1,3 esinemiskorda tuhande sõne kohta ja osakaal $87 \%$ kõigist võima-konstruktsioonidest (näide 23). B2-tasemel on võimalikkuse väljendamise sagedus tõusnud 3,3 esinemiseni tuhande sõne kohta, kuid osakaal vähenenud 57\%-ni (näide 24).

(23) Kui teil on küsimusi, võite pöörduda minu poole täna kella viieni, rõõmuga aitan teid. (B1)

(24) Küsimus on teises, kus see inimene võib töötada oma haridustega. (B2)

Seega on domineeriva modaalsusetüübi osakaal B2-tasemel märgatavalt kahanenud. Selle arvel on B2-tasemele ilmunud muud tüüpi modaalsuse liigid, nagu tõenäosuse (episteemilise modaalsuse, näide 25), põhjendatuse (osalejavälise mittedeontilise modaalsuse, näide 26) jm väljendamine. Nii tõenäosuse kui ka põhjendatuse väljendamist võib pidada modaalsuse abstraktsemateks liikideks.

(25) Võib juhtuda nii, et lapsed võivad aknas klaasid ära lõhkuda. (B2)

(26) Rääkides lühidalt sellest koolitusest, ma võin öelda, et seal me saame oskust, kuidas teisi mõista. (B2) 
Seega on võima-konstruktsioonide funktsionaalne keerukus B2-tasemel arenenud nii funktsionaalsete tüüpide arvu kasvu kui ka abstraktsema tähendusega modaalsuse liikide ilmumise tõttu.

\section{5. võima-konstruktsioonide täpsuse areng}

võima-konstruktsiooni olen hinnanud täpseks, kui see ei mõju mulle kui eesti keelt esimese keelena kõnelejale ei vormiliselt ega sisuliselt häirivalt. Täpsuse vormilist külge olen hinnanud konstruktsiooni peasõna ja selle juurde kuuluva ühe sõna/sõnaühendi ulatuses. Sisulist täpsust hinnates olen arvestanud ka konstruktsiooni laiemat konteksti. Joonisel 8 on kujutatud võima-konstruktsioonide täpsete ja ebatäpsete esinemisjuhtude sagedused.

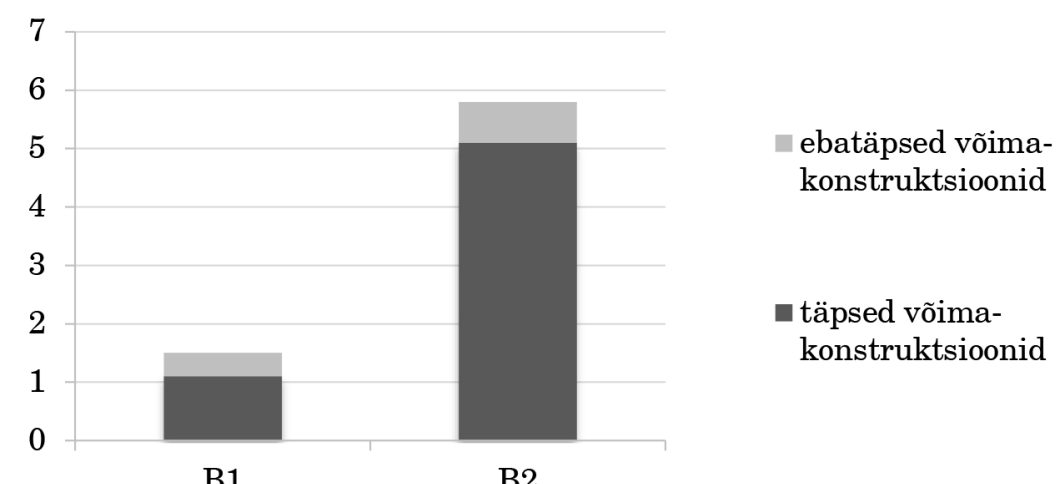

J o on is 8. Modaalverbi võima täpsete ja ebatäpsete konstruktsioonide esinemissagedus. Vertikaaltelg näitab esinemissagedust tuhande sõne kohta.

võima-konstruktsioonidest esineb B1-tasemel täpseid 1,1 korda ja ebatäpseid 0,4 korda tuhande sõne kohta, B2-tasemel on tõusnud nii täpsete $(5,1$ esinemiskorda tuhande sõne kohta) kui ka ebatäpsete konstruktsioonide $(0,7$ esinemist tuhande sõne kohta) sagedus. B1-tasemel moodustab täpsete konstruktsioonide osakaal 73\% esinemisjuhtude koguhulgast, B2-tasemel aga 88\%. Seega kasvab B2-tasemel võima-konstruktsioonide üldine täpsus. Samas kasvab aga ebatäpsete juhtude absoluutarv.

Kokkuvõttes näitavad uurimistulemused, et modaalverbi võima konstruktsioonid on B2-tasemel võrreldes B1-tasemega arenenud morfoloogiliselt, süntaktiliselt, leksikaalselt ja funktsionaalselt. Samuti on B2-tasemel tõusnud modaalverbi võima konstruktsioonide üldine täpsus, samas on veidi tõusnud ka ebatäpsete konstruktsioonide absoluutarv. 


\section{Miks õppijakeele leksikaalgrammatilised konstruktsioonid just niimoodi arenevad?}

Nagu õppijakeele korpuse abil tehtud uurimused näitavad, on tingiva kõneviisi ja modaalverbi võima konstruktsioonid B1- ja B2-taset eristavad keelenähtused, mis arenevad nende tasemete vahel hoogsalt. Lisaks esinemissageduse mitmekordsele tõusule muutuvad nad morfoloogiliselt, süntaktiliselt ja leksikaalselt ning võima-konstruktsioonid ka funktsionaalselt keerukamaks. Samuti muutuvad mõlemad konstruktsioonid üldiselt täpsemaks, kuid samas tõuseb kummagi puhul veidi ka ebatäpsete esinemisjuhtude absoluutarv. Kuigi tegemist on kahe eri tüüpi konstruktsiooniga (tingiva kõneviisi konstruktsioonid on grammatilise kategooria kesksed ja võima-konstruktsioonid verbikesksed), toimub nende üldine areng üsna sarnaselt.

Üksikasjalik info nimetatud konstruktsioonide muutuste kohta on kindlasti väärtuslik: seda saab kasutada nii teaduspõhiste leksikaalgrammatiliste B1- ja B2-taseme kirjelduste loomisel kui ka õppematerjalide ning keeleoskuse määramise süsteemi arendamisel. Samas ei piisa ainult õppijakeele leksikaalgrammatilise arengu täpsest kirjeldamisest eesti keele kui teise keele õppesüsteemi tõhusaks arendamiseks. Et arendada õppesüsteemi, on vaja teada nii seda, mis on mingi taseme õppijakeelele iseloomulik, kui ka seda, miks õppijakeel just sel viisil areneb. Tundes õppijakeele arengu seaduspärasusi ning põhjuseid, saab arengut tõhusamalt toetada ning objektiivsemalt hinnata. $M i k s$-küsimusele vastamiseks jääb aga korpuse uurimistulemustest napiks. Lisaks on vaja teooriat, mis aitaks andmeid mõtestada. Järgnevalt põhjendan oma uurimistulemusi eesti keele kui teise keele jaoks uudsel viisil, tuginedes konstruktsioonigrammatikale (ingl construction grammar; Croft 2001; Goldberg 2003) ja kasutuspõhisele lähenemisele (ingl usage-based approach; vt Larsen-Freeman 1997; Firth, Wagner 1997; Tomasello 2003; MacWhinney 2004; Ellis 2013). Teise keele arengut on sel viisil uurinud põhjamaade teadlased Eskildsen (2008), Martin jt (2010), Mustonen (2015) jt.

Konstruktsioonigrammatika järgi ei koosne keel eraldi sõnadest ja nende kasutusreeglitest ehk grammatikast, mida kombineerides inimesed ennast väljendavad. Konstruktsioonigrammatika on seisukohal, et keel koosneb konstruktsioonidest - keelelistest tervikühikutest, milles sõnad ja nende grammatilised vormid on omavahel lahutamatult põimunud. Igal konstruktsioonil on vorm (sõnad ja nende grammatilised kujud), tähendus (kuidas seda keeleüksust üldiselt mõistetakse) ja suhtlusfunktsioon (mis eesmärgil seda keeleüksust kasutatakse) (Goldberg 2003: 219-220). Konstruktsioonigrammatika järgi tekivad konstruktsioonid kasutuspõhiselt nii keeles tervikuna kui ka iga keeleomandaja keeles individuaalselt (Tomasello 2003; Ellis, LarsenFreeman 2009; Ellis 2013). Keeles tervikuna tähendab see, et inimeste koostegutsemise reguleerimisel ning ühiseid arvamusi, uskumusi, emotsioone jm jagades arenevad inimeste kasutatavad keelelised üksused sümbolilisteks konstruktsioonideks. Konstruktsioonid esinevad eri keeletasanditel ning on eri pikkuse ja abstraktsusastmega. Omavahel põimudes moodustub konstruktsioonidest keelekogukonda ühendav võrgustik, mille keskmes on sagedamini kasutatavad ja seetõttu stabiilsemad tuumkonstruktsioonid ning ääre pool harvemini kasutatavad muutlikumad konstruktsioonid. Keeleomandajad 
õpivad nii esimest kui ka teist keelt neid ümbritsevast keelekeskkonnast konstruktsioone järk-järgult märkama hakates, „üles korjates” ning ise kasutada proovides. Teise keele omandamisel on esimese keele võrgustik seejuures nii toeks (paljud konstruktsioonid esinevad mõnedes või koguni paljudes keeltes) kui kohati ka takistuseks (nõudes olemasolevate keeleteadmiste ümberstruktureerimist) (vt Kaivapalu 2005, 2017).

Kõigepealt hakkavad keeleomandajad sisendkeelest märkama ja üles korjama tervikkujul keeletükke (ingl chunks), mis esinevad keeles sageli, on piisavalt esilduvad ning keeleomandajaile ka kognitiivselt jõukohased, nt ma ei tea. Keeleomandamise alguses kasutavad inimesed peamiselt selliseid valmistükke, neile ise palju lisamata. Kui keeleomandaja on keeletükki piisaval hulgal kuulnud ja kasutanud, hakkab tema teadvuses tekkima konstruktsiooni abstraktne mudel, nt ma ei + tegevust väljendav sõna. Selle mudeli põhjal saab inimene ise moodustada analoogseid konstruktsioone, mida ta täpselt sellisel kujul varem kuulnud pole, nt ma ei taha, ma ei tule (Eskildsen 2008).

Kasutamise käigus juurduvad konstruktsioonid üha rohkem keeleomandaja teadvusse, hakkavad laienema ja omavahel kombineeruma. Laienemine võib toimuda nii morfoloogiliselt, süntaktiliselt ja leksikaalselt kui ka funktsionaalselt (Martin jt 2010; Mustonen 2015). Üldiselt kasvab madalamatel keeleoskustasemetel sihtkeeles sagedaste ja kognitiivselt lihtsamate konstruktsioonide sagedus. Kõrgemal tasemel hakkab osa lihtsamate konstruktsioonide sagedus langema ja nad asenduvad sihtkeeles harvemini esinevate ja kognitiivselt keerukamate konstruktsioonidega - konstruktsioonid võistlevad pidevalt oma koha nimel. Teise keele konstruktsioonid peavad lisaks võistlema ka esimese keele konstruktsioonidega. Seega ei ole teise keele areng kunagi sirgjooneline ega stabiilne, vaid pigem kõikuv. Eri konstruktsioonid arenevad eri ajal, eri mahus ja eri kiirusega ning konstruktsioonide arengus vahelduvad sujuvama ja hoogsama arengu faasid. Kui konstruktsioon jõuab hoogsa arengu faasi, mil keeleomandaja hakkab seda aktiivselt ise moodustama, võib toimuda ajutine tagasilöök keelelises täpsuses ehk kasvab nn keelevigade arv. Alles siis, kui keeleomandaja on saanud uut konstruktsiooni piisavalt palju ise moodustada, hakkab selle täpsus tõusma. Mida rohkem autentset sisendit on keeleomandajale kättesaadav ja mida rohkem ta ise keelt autentsetes situatsioonides kasutab, seda täpsemaks ta keel üldjuhul muutub (Eskildsen 2008; Martin jt 2010; Mustonen 2015). Ideaaljuhul saavutavad õppijakeele konstruktsioonid lõpuks sihtkeeleläheduse, kuid paljude teise keele omandajate mitmed konstruktsioonid ei jõua sellise olukorrani kunagi ja jäävad alati sihtkeelest veidi erinevaks.

Järgnevalt analüüsin tingiva kõneviisi ja modaalverbi võima konstruktsioonide arenguradasid, lähtudes kasutuspõhisest lähenemisest. Pean konstruktsiooni vormi, tähenduse ja suhtlusfunktsiooni terviküksuseks, kuid uurimise eesmärgil vaatlen eraldi morfoloogilist, süntaktilist ja leksikaalset vormi ning tähendust või suhtlusfunktsiooni. Et olen uurinud kaht keskmist keeleoskuse arengutaset B1 ja B2, ei ole ma saanud jälgida kummagi konstruktsiooni esmast keelde ilmumist, mis on suure tõenäosusega toimunud juba A-tasemel. Uurimistulemuste põhjal tundub aga, et nii tingiva kõneviisi kui ka võima-konstruktsioonid on B1-tasemel üsna oma arenguraja alguses. Seda näitab esiteks nende suhteliselt madal esinemissagedus B1-tasemel, millele 
järgneb sageduse mitmekordne tõus B2-tasemel. Sageduse järsu tõusu põhjal võib eeldada nende konstruktsioonide viibimist B1- ja B2-taseme vahel hoogsa arengu faasis. Uurides lähemalt kummagi konstruktsiooni keerukuse muutust, on näha, et B1-tasemel esinevad nii tingiva kõneviisi kui ka modaalverbi võima konstruktsioonid üsna piiratud kujul ning B2-tasemel on toimunud konstruktsioonide märgatav laienemine.

Morfoloogiliselt esineb tingiva kõneviisi konstruktsioonide peasõna B1-tasemel domineerivalt ainsuse esimese pöörde vormis. B2-tasemel on ainsuse esimese pöörde osakaal vähenenud ning tingiva kõneviisi teiste morfoloogiliste vormide osakaal tõusnud. Modaalverbi võima konstruktsioonide peasõna esineb B1-tasemel mitmes morfoloogilises vormis, kuid kõigis neis madala sagedusega. B2-tasemel on kasvanud paljude vormide sagedus, sh eriti kognitiivselt keerukamate kindla kõneviisi ainsuse kolmanda pöörde ja tingiva kõneviisi vormid. Seega laienevad nii tingiva kõneviisi kui ka modaalverbi võima konstruktsioonid morfoloogiliselt.

Süntaktiliselt domineerib tingivas kõneviisis kummalgi tasemel suure ülekaaluga üks tüüp: verb tingivas kõneviisis + verbi infinitiivivorm. B2-tasemel on domineeriva tüübi osakaal siiski veidi vähenenud ning konstruktsioon ka teistesse tüüpidesse laienenud. võima-konstruktsioonidki esinevad B1-tasemel süntaktiliselt piiratud kujul, peamiselt vaid kahes tüübis: võima pöördeline vorm koos verbi infinitiivivormiga ja sihitise või määruse rollis käändsõna(ühendi)ga. B2-tasemel on konstruktsioonid aga laienenud veel nelja süntaktilisse tüüpi. Samuti on tõusnud infinitiivivormi ja sihitise rollis käändsõna(ühendi)ga vormi kui kognitiivselt keerukama tüübi sagedus ja osakaal. Nii on kumbki konstruktsioon laienenud ka süntaktiliselt.

Leksikaalselt esinevad tingiva kõneviisi konstruktsioonid B1-tasemel piiratud arvu verbidega (kokku kaheksa verbiga ning seejuures peamiselt vaid kahega). B2-tasemel esineb tingiv kõneviis aga kokku 23 verbiga (mille hulgas on pooled eesti keeles väga sagedased ja pooled vähem sagedased), sh valdavalt kaheksa verbiga. võima-konstruktsioonides kuulub võima juurde B1-tasemel 31 eri verbi, B2-tasemel aga 63 ehk kaks korda rohkem. Seega on kumbki konstruktsioon B2-tasemel leksikaalselt märgatavalt laienenud.

Funktsionaalselt väljendatakse tingiva kõneviisi konstruktsioonidega nii B1- kui ka B2-tasemel nelja üldist suhtlusfunktsiooni. võima-konstruktsioonid on B2-tasemel arenenud ka funktsionaalselt. B1-tasemel väljendatakse nende konstruktsioonidega kaht modaalsuse liiki, millest üks (võimalikkuse väljendamine) selgelt domineerib. B2-tasemel väljendatakse võima-konstruktsioonidega aga kuut modaalsuse liiki (sh kognitiivselt keerukamaid) ning võimalikkuse väljendamise osakaal on tunduvalt vähenenud. Niisiis on võimakonstruktsioonid funktsionaalses mõttes selgelt laienenud.

Vaadates tingiva kõneviisi ja võima-konstruktsioonide täpsuse muutust kahe taseme vahel, on näha väga sarnane muster. B1-tasemel on kummagi konstruktsiooni esinemisjuhtudest täpseid umbes $70 \%$ ning ebatäpseid $30 \%$ ning B2-tasemel on täpsete konstruktsioonide osakaal tõusnud tunduvalt üle $80 \%$. Samas on märgata ka kummagi konstruktsiooni ebatäpsete esinemisjuhtude absoluutarvu tõusu B2-tasemel. 


\section{Kokkuvõte}

Kasutuspõhise keeleomandamise teooria annab õppijakeele uurimise tulemustele hea seletuse. Selgub, et õppijakeele piiratud kujul esinemine madalamal keeleoskustasemel on keelearengu loomulik etapp, millele järgneb konstruktsioonide eri viisil laienemine kõrgemale tasemele jõudes. Tundub, et nii tingiva kõneviisi kui ka modaalverbi võima konstruktsioone kasutatakse B1-tasemel vähemalt osaliselt veel pigem meeldejäänud keeletükina kui ise moodustades. B2-tasemel on kasutajail aga arenenud nende konstruktsioonide abstraktne mudel ja nad moodustavad konstruktsioone palju aktiivsemalt, mistõttu konstruktsioonid on märgatavalt laienenud. Seejuures on B2-tasemel lihtsamate konstruktsioonitüüpide omandamise tõttu ilmselt vabanenud kognitiivset jõudu keerukamate konstruktsioonitüüpide märkamiseks sisendkeeles ja nende kasutada proovimiseks. Konstruktsioonide üldine täpsus B2-tasemel tõuseb, kuid ka ebatäpsete juhtude absoluutarv tõuseb veidi. Seegi vastab kasutuspõhise lähenemise põhimõtetele: iseseisva aktiivse moodustamise faasis on konstruktsioon mõjutatud ka teistest konkureerivatest konstruktsioonidest, mis põhjustab teatud ebastabiilsuse. Nii ei tähenda nn keelevigade lisandumine mitte halvasti omandatud keelt, vaid võib olla hoopis kiire keelelise arengu tunnuseks.

Et just tingiv kõneviis ja modaalverbi võima konstruktsioonid on B1- ja B2-taseme vahel hoogsa arengu faasis, on kooskõlas ka kommunikatiivse keelepädevuse arenguga. Üheks B1- ja B2-taset eristavaks kommunikatiivseks näitajaks on asjaolu, et kui B1-tasemel on isik võimeline edastama lihtsat infot otsesel viisil, siis B2-tasemel lisandub oskus väljenduda paindlikumalt ning kasutada lisaks informaalsele ka formaalsemat registrit. Selliseks keelekasutuseks vajalike leksikaalgrammatiliste vahendite hulka sobivad nii tingiv kõneviis kui ka modaalverbi võima konstruktsioonid väga hästi - nende abil saab muuta otsese infoedastuse paindlikumaks, varieeruvamaks ja viisakamaks.

Selle kohta, kuidas uurimismaterjaliks olevate tekstide autorid on eesti keelt omandanud, ei ole andmeid. Samas on teada, et enamikus kasutuses olevates õppematerjalides ja õppemetoodikas ei käsitleta üldjuhul tingiva kõneviisi ega modaalverbi võima kasutust seoses eri vajadustega eri keeleoskustasemetel. Nii võib küllalt suure tõenäosusega öelda, et keeleline areng nende konstruktsioonide osas tõestab keeleomandamise kasutuspõhisust. Kokkuvõttes saab ka kinnitada, et õppijakeelekorpus on õppijakeele arengu uurimiseks suurepärane abivahend. Autentse korpusmaterjali põhjal on võimalik analüüsida, kuidas keeleomandajad keelt oma arengu eri etappidel kasutavad. Miks nad seda aga just sel või teisel viisil teevad, selle seletamiseks on lisaks vaja head teooriat.

\section{Kirjandus}

Allkivi, Kais 2016. C1-tasemega eesti keele õppijate ja emakeelekõnelejate kirjaliku keelekasutuse võrdlus verbialguliste tetragrammide näitel. - Lähivõrdlusi. Lähivertailuja, nr 26, lk 54-83. 
Cr oft, William 2001. Radical Construction Grammar: Syntactic Theory in Typological Perspective. Oxford: Oxford University Press.

$\mathrm{EKR}=$ Euroopa keeleõppe raamdokument. Õppimine, õpetamine ja hindamine. Tartu: Haridus- ja Teadusministeerium, 2007.

EKSS = Eesti keele seletav sõnaraamat I-VI. Toim Margit Langemets, Mai Tiits, Tiia Valdre, Leidi Veskis, Ülle Viks, Piret Voll. Eesti Keele Instituut. Tallinn: Eesti Keele Sihtasutus, 2009. http://www.eki.ee/dict/ekss

Ellis, Nick C. 2013. Second language acquisition. - Oxford Handbook of Construction Grammar. Toim Thomas Hoffmann, Graeme Trousdale. Oxford: Oxford University Press, lk 365-378.

Ellis, Nick C., Larsen-Freeman, Diane 2009. Constructing a second language: Analyses and computational simulations of the emergence of linguistic constructions from usage. - Language Learning, kd 59, nr S1, lk 93-128.

Erelt, Mati 2013. Eesti keele lauseõpetus. Sissejuhatus. Öeldis. Tartu: Tartu Ülikooli Kirjastus.

Eskildsen, Søren Wind 2008. Constructing a Second Language Inventory. The Accumulation of Linguistic Resources in L2 English. (PhD dissertation.) Odense: Institute of Language and Communication University of Southern Denmark.

E s lo n, Pille 2011. Millest räägivad eesti keele käändeasendused? - Lähivõrdlusi. Lähivertailuja, nr 21, lk 45-64.

Eslon, Pille 2012. Objekti ja tegevuse markeeritus eesti õppijakeeles. - Lähivõrdlusi. Lähivertailuja, nr 22, lk 15-42.

E s l o n, Pille 2014a. Eesti vahekeele korpus. - Keel ja Kirjandus, nr 6, lk 436-451.

Eslon, Pille 2014b. Adverbi sisaldavate struktuuride tekstifunktsioonidest eesti ilukirjandus- ja õppijakeeles. - Lähivõrdlusi. Lähivertailuja, nr 24, lk 15-46.

Eslon, Pille 2014c. Morfosüntaktilise ja leksikaalse varieerumise piiridest: ilukirjandus- ja õppijakeele kasutusmustrite võrdlus. - Eesti Rakenduslingvistika Ühingu aastaraamat, nr 10, lk 55-71.

Eslon, Pille 2017. Keelekasutusmustrid verbist paremal: morfosüntaktiline ja leksikaalsemantiline varieerumine. - Lähivõrdlusi. Lähivertailuja, nr 27, lk 17-64.

Fir th, Alan, W a g n er, Johannes 1997. On discourse, communication, and (some) fundamental concepts in SLA research. - Modern Language Journal, kd 81, nr 3, lk 285-300.

Franceschin a, Florencia, Al a nen, Riikka, Hu hta, Ari, Martin, Maisa 2006. A progress report on the Cefling project. Ettekanne. SLATE Workshop, Amsterdam.

Gold berg, Adele 2003. Constructions: a new theoretical approach to language. Trends in Cognitive Sciences, kd 7, nr 5, lk 219-224.

Hausenberg, Anu-Reet, Ilves, Marju, Kaivapalu, Annekatrin, Kerge, Krista, Ker n, Katrin, Kitsnik, Mare, Krall, Ingrid, Ru m m o, Karin, Rü ütm a a, Tiina 2008. Iseseisev keelekasutaja. B1- ja B2-taseme eesti keele oskus. Tallinn: REKK, Atlex.

Housen, Alex, Kuiken, Folkert, Vedder, Ineke 2012. Complexity, accuracy and fluency. Definitions, measurement and research. - Dimensions of L2 Performance and Proficiency. Complexity, Accuracy and Fluency in SLA. Toim A. Housen, F. Kuiken, I. Vedder. Amsterdam-Philadelphia: John Benjamins, lk 1-20. 
Ilves, Marju 2008. Algaja keelekasutaja. A2-taseme eesti keele oskus. Tallinn: EKSA.

Ilve s, Marju 2010. Läbimurre. A1-taseme eesti keele oskus. Tallinn: EKSA.

Ka alep, Heiki-Jaan, Muis chnek, Kadri 2002. Eesti kirjakeele sagedussõnastik. Tartu: TÜ Kirjastus.

Kaivapalu, Annekatrin 2005. Lähdekieli kielenoppimisen apuna. (Jyväskylä Studies in Humanities 44.) Jyväskylä: Jyväskylän yliopisto.

Kaivapalu, Annekatrin 2017. Õppija teekond: sarnasuse tunnetamisest sihtkeelepärase kasutamiseni. - Mäetagused, nr 69, lk 243-264.

Ke r g e, Krista 2008. Vilunud keelekasutaja. C1-taseme eesti keele oskus. Tallinn: EKSA.

Kitsnik, Mare 2014. Verbivormid B1- ja B2-taseme kirjalikus õppijakeeles. ESUKA / JEFUL, kd 5, nr 3, lk 9-35.

Kitsnik, Mare 2015. Tingiv kõneviis eesti B1- ja B2-taseme kirjalikus õppijakeeles kui keeleoskuse arengu näitaja. - Lähivõrdlusi. Lähivertailuja, nr 25, lk 137-171.

Kitsnik, Mare 2017. Modaalverbide saama ja võima konstruktsioonid B1- ja B2-taseme kirjalikus õppijakeeles kui keeleoskuse arengu näitaja. - Eesti Rakenduslingvistika Ühingu aastaraamat, nr 13, lk 19-36.

L a r sen-Freem a n, Diane 1997. Chaos/complexity science and second language acquisition. - Applied Linguistics, kd 18, nr 2, lk 141-165.

M a c W h in ney, Brian 2004. A unified model of language acquisition. - Handbook of Bilingualism: Psycholinguistic Approaches. Toim Judith F. Kroll, Annette De Groot. Oxford: Oxford University Press, lk 49-67.

M a i s la, Diana 2014. Eesti keele mineviku ajavormid vene emakeelega üliõpilaste kasutuses (Dissertationes philologicae estonicae Universitatis Tartuensis 20.) Tartu: Tartu Ülikooli Kirjastus.

Martin, Maisa, Mustonen, Sanna, Reiman, Nina, Seilonen, Marja 2010. On becoming an independent user. - Communicative proficiency and linguistic development: intersections between SLA and language testing research. (Eurosla Monographs Series 1.) Toim Inge Bartning, M. Martin, Ineke Vedder. EUROSLA, lk 57-80.

Must on en, Sanna 2015. Käytössä kehittyvä kieli. Paikat ja tilat suomi toisena kielenä oppijoiden teksteissä. (Jyväskylä Studies in Humanities 255.) Jyväskylä: Jyväskylän yliopisto.

Tomasello, Michael 2003. Constructing a Language: A Usage-Based Theory of Language Acquisition. Harvard University Press.

\section{Võrguviited}

English Profile. http://www.englishprofile.org (11. V 2018).

EVKK = Eesti vahekeele korpus. http://evkk.tlu.ee (11. V 2018).

Innove tasemeeksamite statistika. https:/www.innove.ee/eksamid-ja-testid/eestikeele-tasemeeksamid/statistika/ (11. V 2018).

LanguagePolicyPortal.http://www.coe.int/t/dg4/linguistic/DNR_EN.asp\#P66_9442

(11. V 2018). 
LCA = Learner Corpus Association. http://www.learnercorpusassociation.org (11. V 2018).

ÕKK = Tartu Ülikooli õppijakeelekorpus. http://www.keel.ut.ee/et/keelekogud (11. V 2018).

Mare Kitsnik (snd 1962), PhD, Tartu Ülikooli rakenduslingvistika osakond, eesti keele võorkeelena didaktika vanemteadur, mare.kitsnik@ut.ee

\section{Estonian learner language development - how and why: addressing an interlanguage corpus}

Keywords: communicative language competence, lexicogrammatical language competence, linguistic constructions, usage-based approach, complexity, precision, Estonian as a second language

The article addresses the development of lexicogrammatical competence in written Estonian (learnt as a second language) from the B1 to B2 CEFR levels. The research material consists of performances in the writing tasks of the state exams of Estonian as a second language and it comes from the Estonian Interlanguage Corpus (EVKK). The study is focused on constructions with the modal verb võima 'can, may, be allowed' and the conditional mood constructions, whose frequency in the B2 level increases significantly compared to the B1 level. Based on the CAFtriad (Housen et al. 2012) and using the DEMfad model (Franceschina et al. 2006; Martin et al. 2010) the morphological, syntactical, lexical and functional distribution and the accuracy of the constructions have been analysed, while signs of rapid development have been revealed in most of the areas explored. The development of the two construction types is explained using constructional grammar (Goldberg 1995; Croft 2001) and the usage-based approach to second language acquisition (Larsen-Freeman 1997; Firth, Wagner 1997; Tomasello 2003; MacWhinney 2004; Ellis 2013). The conclusion reads that between the B1 and B2 levels the development of conditional mood constructions as well as of the constructions with the modal verb võima follow the main principles of development of second language constructions.

Mare Kitsnik (b. 1962), PhD, University of Tartu, Department of Applied Linguistics, Senior Research Fellow in Estonian as Foreign Language, mare.kitsnik@ut.ee 